\title{
Implications of the EU Information and \\ Consultation Directive and the Regulations in \\ the UK - The future prospects of employee \\ representation
}


Implications of the EU Information and Consultation Directive and the Regulations in the UK - Prospects for the future of employee representation

\author{
Paul J. Gollan \\ Department of Business \\ Macquarie University \\ and \\ Industrial Relations Group \\ London School of Economics \\ Houghton Street \\ London \\ WC2A 2AE \\ and \\ Adrian Wilkinson* \\ Department of Industrial Relations \\ Griffith Business School \\ Griffith University \\ Nathan \\ Queensland 4111 \\ Australia
}




\title{
Implications of the EU Information and Consultation Directive and the Regulations in the UK-Prospects for the future of employee representation
}

\begin{abstract}
The EU Directive on informing and consulting employees (I\&C Directive) is now established on the employment relations agenda with the provisions coming into force in the UK in April 2005. The I\&C Directive potentially has far reaching consequences for the way UK employers inform and consult employees over a wide range of organisational issues, with the potential to transform the UK industrial relations environment. The initiatives contained in the I\&C Directive and the subsequent introduction of the Information and Consultation of Employees (ICE) Regulations will take place in an employment relations environment in a period of significant change. Pressures of globalisation have intensified competition in product and labour markets, emphasising the need for greater efficiency and productivity. This has led to a greater focus on the link between employee participation practices and business strategy and organisational performance in search of an elusive (or illusory) fit? This paper is a commentary on the origins and rationale of this new legislation in the UK context, drawing on existing knowledge and academic debates in the area. In addition, the paper discusses the potential implications of the I\&C Directive and the likely impact of the ICE Regulations on UK representative voice arrangements.
\end{abstract}




\section{Introduction}

The EU Directive on informing and consulting employees (I\&C Directive) is now established on the employment relations agenda with the Information and Consultation of Employees (ICE) Regulations based on the I\&C Directive coming into force in the UK on the $6^{\text {th }}$ of April $2005^{1}$. According to John Monks, the then TUC General Secretary the Information and Consultation Directive is 'potentially the most significant piece of employment legislation ever to be introduced in the UK.' The Directive could have far reaching consequences for the way UK employers inform and consult employees over a wide range of organisational issues, with the potential to transform the UK industrial relations environment. However, the realisation of this potential will depend on the strategies of employers and the response by trade unions to these initiatives.

This paper is a commentary on the origins and rationale of this new legislation in the UK context, drawing on existing knowledge and academic debates in the area. This paper outlines the thinking behind the Directive and the basic principles. We then look at the Directive in the context of the state of UK consultation more generally. We also examine how current law shapes consultation in the UK. We discuss the challenges and potential impact of the ICE Regulations and explore the future prospects and implications for workplace representation more generally in the UK.

\section{The Information and Consultation Directive}

The purpose of the Directive is to establish a general framework of minimum requirements for the right to information and consultation of employees. The Directive requires employers to inform and consult employee representatives about employment prospects and decisions likely to lead to substantial changes in work organisation or contractual relations. More specifically, the Directive places employers under a legal obligation to inform their staff on an ongoing basis about matters such as firm performance and strategic planning. Although it does not make employee representative structures compulsory, this may prove necessary to meeting

\footnotetext{
${ }^{1}$ Under European requirements, European Directives are required to be transposed into domestic national legislation before they become law.
} 
its requirements, which include evidence of a procedure. The text was agreed by the European Parliament in December 2001 and officially came into force in March $2002^{2}$.

The UK and Eire were granted later implementation dates for smaller companies. The UK and Eire are most affected by the Directive's requirements because they currently do not have any general permanent and statutory system of Information and Consultation (Hall et al., 2002). Other EU Member States already have a range of workplace consultation requirements, and it is expected that fewer legal changes will be required in these countries. Newly acceding countries to the EU in May 2004 will also be required to implement the Directive by March 2005 (CIPD, 2004).

Information and Consultation are defined as taking place between the employer and employee representatives. The Directive requires:

- information on the recent and probable development of the undertaking's or the establishment's activities and economic situation;

- information and consultation on the situation, structure and probable development of employment and on any anticipatory measures envisaged, in particular where there is a threat to employment; and

- information and consultation, with a view to reaching an agreement, on decisions likely to lead to substantial changes in work organisation or in contractual relations.

Under the I\&C Directive, information in this context means the provision of data on the business - whether on workplace issues or more strategic matters - to employees or their representatives, which allows workers to participate in dialogue with employers. Consultation is concerned with the exchange of views between employers and employees or their representatives, but stops short of bargaining, so that responsibility for decision-making ultimately remains with management.

\footnotetext{
${ }^{2}$ Under the UK ICE Regulations businesses with more than 150 employees were covered from $6^{\text {th }}$ of April 2005. Those with more than 100 employees will be covered from $6^{\text {th }}$ of April 2007. Those businesses with at least 50 employees will be covered from $6^{\text {th }}$ of April 2008. The law is universal in its coverage, apart from small firms with less than 50 employees.
} 


\section{Information and Consultation Directive in context}

In this section we explain the background and context for the Directive and the debates over how it was to be operationalised.

\section{Political background to the I\&C Directive}

In most European countries, participation structures exist within the framework of statutory works councils, where co-decision making rights extend the entitlement of employees to information and consultation on certain issues. The process of consultation lies within a broader framework of organisational arrangements that directly or indirectly contribute to shaping the process of employee participation.

The Industrial Society ${ }^{3}$ has suggested that the debate over employee information and consultation is more than just an economic imperative (or in other words 'good for business') or a rationalisation of the law (too much and too complex legislation) (Burns, 2000). Fundamental to this debate is the underlying argument that employees and their representatives have a right to be consulted and 'to have a say at work' or what is sometimes referred to as 'industrial citizenship’. This argument is concerned with the principles of democracy and citizenship. If people have political democratic rights and civil rights under law, then industrial citizenship rights should not be excluded. Under current company law, shareholders are the focus of the decision-making process, with employees accorded secondary importance in the process.

Indeed a call for further EU action regarding consultation rights was made after the closure of the Renault plant at Vilvoorde in Belgium because the consultation processes were seen as inadequate under EU legislation. Following this case, the Commissioner responsible for social affairs and employment at the time, Pádraig Flynn, reaffirmed his commitment to extend employee consultation rights. In June 1997 the Commission initiated a first round of consultations on the advisability of legislation based on the procedure outlined in the social policy Agreement annexed to the Maastricht Treaty.

As such, the European Directive on a general framework for informing and consulting employees goes well beyond voice as a communication or a consultation arrangement per se. Clearly, the spirit of the Directive (if not the letter of the law) is to

\footnotetext{
${ }^{3}$ Now called the Work Foundation.
} 
provide greater involvement in and influence on decision-making processes. The European Commission in 1998 stated the aim of the Directive was to not only keep employees informed of management decisions but, more broadly provide, as a social objective, enhanced employee rights, and increasing employee involvement over a range of enterprise issues.

In November 1998, the European Commission proposed a Council Directive establishing a general framework for informing and consulting employees. The European Commission (1998) stated that:

This initiative is an essential step in completing the EU's social dimension and in achieving the creation of an adaptable, high-skilled and motivated workforce, because of the role of information and consultation in developing adaptability and contributing to increases in productivity. The Commission suggests that this proposal complements existing national and EU provisions and legislation, and seeks to 'fill the gaps and inadequacies that have been identified in the long process of consultation'. In other words, the proposal is seen by the Commission as building upon the 'piecemeal' nature of existing community law, enhancing the impact of the existing Directives on collective redundancies and safeguarding employees’ rights in the event of transfers of undertakings. It was argued that creating a general framework for employee information and consultation at the EU level would make these legislative provisions more effective, comprehensive and workable. The Commission also highlighted that 'consultation between employer and employee is based on a dialogue and exchange of views' including decisions likely to lead to substantial changes concerning work organisation and contractual relations and an 'attempt to seek prior agreement on the decision concerned' (European Commission, 1998).

Importantly, speaking after the adoption of the proposal, the then Employment and Social Affairs Commissioner, Pádraig Flynn, stated:

This is an important day for social Europe, as, after a long phase of preparation and consultation, we are presenting an important tool in the search for greater adaptability in the workforce. The Commission's proposal provides a framework within which the Member States and the social partners can ensure an effective and balanced involvement of workers in a more positive and flexible approach to reorganisation and 
change, especially the modernisation of work organisation (European Commission, 1998).

It has been argued that transposing EU directives into UK legislation is likely to lead to a proliferation of employee representation structures for different purposes. As Bercusson notes, 'From a tradition of single channel employee representation, British labour law moving in the opposite direction from the American "trade union representational monopoly", has skipped over continental dual channel systems into multi-channel employee representation systems' (2002: 234). He goes on to state that while the new Directive will require the establishment of new organs of worker representation, it also raises the question of the criteria for determining who are the workers' representatives, and who can establish and participate in these bodies. He concludes by asking whether UK industrial relations is best served 'by further multiplying the channels of employees representation with different functions' (Bercusson, 2002: 234).

More generally, whether Information and Consultation Directive implementation into UK law will bring British industrial relations practice close to the European social model or whether the flexibility negotiated by the current Blair government over the Directive will provide a tool for 'British Industrial Relations Exceptionalism' (Bercusson, 2002: 209) is open to question.

\section{UK government's response}

The Labour Government has linked the Directive to the concept of the high performance workplace which has become a modern mantra recited by employers, policy makers and the social partners. According to a Department of Trade and Industry (DTI) discussion document, High Performance Workplaces: The role of employee involvement in a modern economy (2002) 'modern, high performance workplaces...build on the simple insight that individuals are more likely to give of their best if they feel valued and are given the opportunity to contribute their ideas; and that people who are well-prepared for change can help to introduce it and thereby help secure employment within the business' (2002: 13).

A key issue is the degree to which the Directive will encourage the adoption of more flexible high performance work systems, as argued in the Government's consultation document. The argument about high performance sits at odds with the 
main EU motivation for introducing the Directive (as part of Social Policy) and may say something about the importance the government has given to the business case for the Directive.

While the Directive offers a substantial degree of flexibility in relation to the shape of information and consultation arrangements, some commentators have suggested that this proposal implies the establishment of national-level works councils in the UK, or at least in non-union establishments some form of non-union employee representation (Gospel and Willman, 2002, 2003). For some, the Directive requires workplace bodies comprising elected representatives and consultation to be structured in such a way that these representatives and their constituencies can influence management decisions. However, the DTI and Chartered Institute of Personnel and Development (CIPD) guidance on the ICE Regulations based on the Directive suggest direct forms of information and consultation with the workforce as a whole is adequate and satisfies an employer's obligation to consult (DTI, 2004:17; CIPD, 2004: 10). However, this may be challenged at a later date. . Gollan (2005) argues that a mechanism solely for communication may not be enough and that voice — a right to be heard and have a say over workplace issues - may be an essential component of worker satisfaction and commitment.

\section{The ICE Regulations}

The ICE Regulations have been drafted to allow significant flexibility in establishing methods of informing and consulting employees so that they suit particular organisations. Under the ICE Regulations this requires ten per cent of the workforce to trigger the ICE Regulations (by signatures or a vote), thus requiring the firm to start formal procedures in establishing arrangements as required under the ICE Regulations. Importantly, the requirement for a ballot of the workforce arises only where an employee request for new information and consultation arrangements is made and the employer already has a 'pre-existing agreement' in place. Under these Regulations an employer may then establish an arrangement covering all employees at the workplace or the request may go to a ballot of employees. If a ballot is called, then 40 per cent plus a majority of those voting must endorse the request. If successful, the 
employer is obliged to reach a negotiated agreement with genuine employee representatives.

Employers that have 'pre-existing' information and consultation agreements covering all employees and have been formally approved by the workforce will only have to consider making changes if they receive a request supported by 40 per cent of employees to negotiate new arrangements. Pre-existing and negotiated agreements allow employers to agree with the workforce information and consultation arrangements that suit the particular size, type and employment culture of the organisation (CIPD, 2005).

Organisations that do not have formally approved information and consultation agreements may be vulnerable to having the Regulations' standard provisions for informing and consulting employees imposed on them if ten per cent of employers make a request. Employers will then be required to negotiate new arrangements but if agreement can not be reached then the standard provisions will apply.

Employers without 'pre-existing agreements' can take the initiative and inform the workforce that they intend to establish new arrangements and negotiate an information and consultation agreement without waiting for an employee request. This allows employers to set the agenda but if negotiations fail and agreement cannot be reached then the standard provisions will again apply. Penalties for noncompliance are to be set by Member States and are to be "effective, proportionate and dissuasive” (see Box 1 for further details).

\section{The challenges of the ICE Regulations}

It has been argued that transposing EU directives into UK legislation is likely to lead to a proliferation of employee representation structures for different purposes (Bercusson, 2002).

Commentators have suggested that the effectiveness of the Directive and the resulting ICE Regulations is questionable given the UK government's less than enthusiastic response to and support for the original proposal in November 1998. The Blair Government was persistent in its reservations blocking and weakening the directive during its drafting. It is argued that this has resulted in a watered down and potentially ineffective piece of legislation. Bercusson argues, 'The Blair government's trench warfare had been successful in gutting much of what was innovative in the proposal' (2002: 237). This point was reinforced by Scott (2002) when he suggested 
'the ferocity with which the UK government represented employers in the four-year negotiation process...indicates a special, systemic fear amongst UK employers...with significant material and symbolic investment in UK's low cost industrial relations regime'

It is said that this weakening of the Directive could significantly reduce its impact in the majority of UK workplaces. Scott argues that it may turn out to be a strategic plan whereby UK unions could find a non-union system of employee representation embedded by clever employers who have learnt a lot in recent years about industrial relations without unions. He argues that 'after many valuable years of fairly straightforward gain from EU social legislation, despite the loss of closed shops and sometimes exhausting legal battles, it now looks as though UK unions have reached a difficult set of crossroads ' (Scott, 2002: 1).

Scott concludes that 'the UK could find itself in a few years without either much in the way of trade union progress on consultation rights, or anything in the way of employee representation that would be recognised as such in mainland Europe. In short, the wide corridors of interpretation and the specific structuring of the directive may leave the UK with the worst of both worlds, neither decent works councils, nor strengthened unions' (2002: 2). While this is arguably an overly pessimistic view, nevertheless the Directive does pose a number of challenges for representation in the UK.

In addition, the research of Peccei et al. (2005: 34) research would seem to indicate that the performance impact of the Directive will be dependent upon existing organisational and institutional conditions, particularly on existing levels of employee organisational commitment and the presence and strength of trade unions at the workplace. Overall, information on performance targets and operational information is likely to yield greatest benefits and outcomes in non-union workplaces with general information having a positive effect in union workplaces.

Notwithstanding these concerns and reservations, the UK ICE Regulations will require more extensive voice arrangements for employees if the establishment is covered by the legislation, and either entered into a voluntary arrangement with employees, or is triggered by the workforce.

\section{Future prospects and implications for workplace representation}


While some may accept the argument that a 'seismic' improvement in employee voice may result from the Information and Consultation Directive and the recent introduction of the ICE Regulations, it is unlikely that these, in themselves, will increase employee voice substantially in many workplaces. It could be argued that the Directive could easily result in 'weak' employer-dominated partnerships and nonunion firms using direct communications and information (allowable under the UK Information and Consultation regulations based on the Directive) while marginalising collective consultation. Managers may provide information and insist on employee involvement but employees have no guarantee of effective consultation in return. It is worth reminding ourselves of the Price case of 1994 and the statement by Lord Justice Gildewell that 'It is axiomatic that the process of consultation is not one in which the consultor is obliged to adopt any or all of the views expressed by the person or body he is consulting'

There is a danger of seeing the legislation as a single shock to the system which will have a once and for all effect. But unlike, say, legislation on the minimum wage or equality this is more likely to be a dynamic process. It may be that employees develop a taste for power and that there is learning (on all sides) which may develop the participation processes further. Managers may become more comfortable and employees more confident, changing an ineffectual consultation process into something with real meaning.

Indeed some commentators have suggested that the European Union concept of social dialogue through partnership between employers and employees by representative voice arrangements—-such as trade unions and works councils based on the idea of 'enlightened' consensual relations and co-operation-is not new in the UK, and draws from a long history of modernisation in British industrial relations (Coupar and Stevens, 1998; Martinez-Lucio and Stuart, 2002; Marchington and Wilkinson, 2005). However, the UK may be left in a situation with neither a strong trade union movement nor an effective system of employee voice. As Scott (2002) has argued:

If the UK is heading for a dual system, something which is a distinctly feasible evolution, what an amazing and appalling innovation it would be to find in a few years that the new Directive had ushered in a mutually exclusive dual system, an either single line union system or a single line 
employer controlled works council system. It would be a distinctly UK mutant hybrid, the worst of both worlds (2002: 6).

It could also be argued that if the information and consultations are regarded by employers as purely a vehicle for communication and information employees will perceive such arrangements as not addressing their concerns and interests and therefore as impotent and ineffective. Therefore, by implication the ICE Regulations could in this scenario be regarded by employees as accomplishing very little in terms of true consultation and thus fail in its objective of ensuring 'effective and balanced involvement of employees' and providing ‘an essential step in completing the EU social dimension and in achieving the creation of an adaptable, high-skilled and motivated workforce' (European Commission, 1998).

So if employee information and consultation is a positive and worthwhile endeavour, why is it unlikely that many will not embrace this more readily? First, it can sometimes be difficult to prove the link between good employee involvement and consultation practices, and organisational performance. In addition, the time period can be an important dimension with employee consultation normally requiring shortterm costs for achieving long-term rewards. At a micro-level perhaps the most difficult obstacle is that effective employee consultation requires a change in culture for managers and employees, which may involve considerable leadership skills, vision, time and resources. At the macro-level, the problems of disconnected capitalism (Thompson, 2003) means that it is difficult for managers-whatever their personal inclinations - to provide the time and flexibility to allow workers to be more involved in a meaningful way. To the extent that they can allow 'bargains', either by negotiation or consultation, these are fragile creatures all too easily wrecked by external forces.

Whatever the evidence on the importance of employee information and consultation for organisational success, it seems likely that firms will be required to review their arrangements as a result of legislation emanating from Europe. In theory it could provide a catapult for change. There may be some converts who, together with the true believers, fall into the category of active adoption (see table I).

One scenario might be those organisations already practising information and consultation will use this as an opportunity to review their structures and processes and fine tune them. There are the true believers. Renewal is the name of the game . 
But this leaves out a large number of employers who may decide do little but keep their heads down, feeling that the trigger might not be pulled by employees so they may as well muddle through. And they may well be right in many cases in that employees may not agitate in the new context. Minimal adoption of participative structures will be evident. However, a redundancy crisis, or major restructuring may awaken 'sleepy' employees and begin the process over which employers will then have much less control, and which may be conducted in a much less amicable environment. Here personnel managers clearly have a role in indicating the possibilities of such a scenario and to advocate for consultation without waiting for employee prompts. Some may feel forced to do 'something' so as to comply with the legislation without being whole hearted believers in the practice. They will go through the motions of ceremonial adoption. However, there may also be some who believe in the value of participation but are unwilling to implement the terms of the ICE Regulations (assent adoption)

For some the Directive represents the 'opportunity to improve the quality of UK industrial relations with the potential for widespread general gains that has come to be associated with the concept of partnership’ (Sisson, 2002: 13). However, legislatively prompted voluntarism (Hall, 2005) may not be enough to provide a platform for a fundamental change in employment relations.

\section{The impact and potential outcomes of the ICE Regulations}

In this section we look sat the potential impact on the key stakeholders in this process

\section{Unions}

It could be suggested that the ICE Regulations provide an opportunity for unions to be activity involved in workplaces where they have no current presence. In workplaces where recognition is already attained it could help deepen the agenda. In other words it provides some impetus to roll back the decline of joint regulation heavily exposed within a voluntarist system and an unsympathetic institutional framework. As noted earlier, WERS reports a narrowing of bargaining and consultation even where it does take place.

Over the last 20 years 'fair weather' collective bargaining could only go so far and the union recognition process has not yielded dramatic results. Hence it is not surprising that some employers regard the directive as a Trojan horse. But of course it 
is also a potential threat to unions as non-union representation could be sponsored and legitimised through this process, either undermining union recognition where it exists or hindering its establishment. In the Directive explicit reference to 'employee representatives' is an indication of a preference or assumption for representative forms of employee voice but this is not automatically via union stewards. Instead, it could include employee representatives elected from and by the workforce.

More broadly, there are a number of uncertainties; if unions want to use the directive to get into virgin workplaces do they have the resources to put workplace representatives into place where there are no members paying subscriptions? Equally will employers use the requirement to inform and consult to move items off the collective bargaining agenda? The relative strength of the union or unions present is likely to be an important consideration here. Where unions are weak and in decline, non union bodies can offer a more substantial representative option. Much depends on management perception of the role unions play. A management perception that an 'outside' influence can distort internal processes and structures, impacting negatively on employee behaviour and organisational performance may mean organisations creating alternative representative bodies to reduce the likelihood of outside involvement by trade unions in organisational decision-making, thus ensuring that consultation processes are contained within the firm (Gollan, 2005). While there is a demand for more indirect representation of voice among British workers, this is not a demand for union voice alone (Gospel and Willman, 2003: 15).

Finally, an important danger is that the ICE Regulations could result in 'weak' employer-dominated partnerships and non-union firms using direct communications but marginalizing collective consultation leading to dissatisfied employees. Indeed, it has been suggested that such employer-initiated structures are based on employers' terms and cannot be effective in providing a true voice for employees’ concerns because they institutionalise worker cooperation, thus limiting scope for trade union action (Kelly, 1996; Lloyd, 1999).

\section{Employers}

The literature identifies several motivations for management to create employee participation structures. One is based on the notion that by allowing workers a 'voice' they provide a mechanism for the early detection of problems or grievances. Fernie and Metcalf (1995) state that the consultation process implied by the existence of the 
joint consultative committee makes it easier to change working practices and introduce new technology, leading to faster productivity growth both in unionised and non-union workplaces. Research into the European car components industry identify that more participative employee practices, including representative participation, impact positively on business performance (Sako, 1998). This has included improvements in quality, communication and the quality of decision-making. Another motivation is to allow workers' participation in decisions that could impact positively on productivity and quality, or finally as a means to avoid trade union representation arrangements.

Context is important and was reflected in a consensus concerning the ICE Regulations implementation that one size would not fit all. There are different pressures and issues in different contexts. Small firms usually have less formalised procedures and less staff dedicated to specialist human resource (HR) work and will be the most challenged in attempting to meet the demands of the directive. The unitary conception of the firm held by managers will be an issue. In unionised workplaces, management will have to decide how to work with recognised unions to set up the new arrangements. In contrast, in non-union workplaces, management will have to consider how to blend them in with their current non-union practices. Finally, in the public sector, management is under different kinds of pressures compared with the private sector, and it has to communicate different kinds of information to its employees-less pressures of commercial survival, but more pressures related to the objectives set by ministers and public service agreements. Likewise, manufacturing has long had a different employment relations ethos from services, and currently, its economic fortunes have been rather different from services.

The view that the directive would produce seismic change is not supported by the comments of Digby Jones, Confederation of British Industry (CBI) Chief who claimed that:

These new rules will be irrelevant to most companies because they already have systems that employees are happy with arrangements for discussing developments with them. Few employers have to be told its good business practice to make sure staff know what's going on and they don't need legislation to make them do it.” (quoted by Reade, 2005). It is instructive that the CBI has tended to interpret the legislation in terms of promoting a message of direct participation e.g. job enrichment, self managing and 
communication. This fits with research which suggests managers saw voice not as grievance or joint regulation but as primarily concerned with problem solving (Wilkinson, et al., 2004).

For most commentators, the ICE Regulations has focussed attention on representative participation, but what does this mean for the future of direct participation? We know there is little switching from indirect to direct participation or vice versa (Gospel and Willman, 2003), so those organisations which have direct participation alone will probably adopt a dual track approach. Professional bodies such as the Chartered Institute of Personnel and Development (CIPD) have argued it is crucial that direct participation is not neglected in the process of developing representative structures (Emmott, 2003) and point to how the combination of direct and indirect consultative arrangements has the potential to improve organisational performance (Beaumont and Hunter, 2003). This raises the issue of how the two interact and much depends on management motivation. Representative participation may be introduced only as bureaucratic requirement with purely ceremonial adoption or it could be used to do something rather ambitious in developing employee voice.

Information and consultation initiatives cannot be analysed in isolation from the other company policies that impact on the employment relationship. The credibility and acceptance of any initiative is partly governed by management's treatment of the workforce (Guest, 1992). Therefore, the organisation's HR policies and the level of trust in management need to be considered.

\section{Government and Policy}

The Government's lack of enthusiasm for the ICE Regulations has been well documented and reflected in the minimalist approach taken where 'light touch' and the avoidance of 'gold plating' dominate thinking (Hall, 2005). A key policy issue relates to training. It is clearly naive to think that a new process is likely to change attitudes itself or that those involved can take on new roles and styles without additional training/support given that many employees and employees have little experience of consultation processes.

The current UK implementation of I\&C is maintaining the voluntarist tradition albeit within a statutory framework. On the one hand it could institutionalise participation on a permanent basis through a mix of coercive, mimetic and normative forces (Scott, 1995). In practice, however it may represent another missed opportunity 
along the meandering peculiarities of British attempts to reform its employment relations system.

If one looks on the Directive as having the potential to transform workplace relations an institutional theory lens perspective can help (Gollan, 2006). Industrial relations could be seen as largely looking at change through a (coercive) vehicle. However, the other two mimetic and normative are clearly relevant and the state can 'shape the cognitive and normative rules that undergird employer decision process beyond that of the law (Goddard, 2002: 249).

Of course the regulations were designed as a 'floor of rights' — rather than a 'ceiling' - but even the notion of a 'floor' is misleading; these are not automatic rights possessed by individuals, but need to be triggered to bring about a collective right. This is despite Sisson's (2002) argument that “the right to be informed and consulted at work is as fundamental as the right not to be unfairly dismissed or to be discriminated against.” Recent research conducted into employees' knowledge of the legal requirements concerning information and consultation suggest that more than eight in ten employees in the UK have not heard of the I\&C Directive. Only 12 per cent of employees have been informed of these requirements from their employer, and almost all (94\%) have not been told about these requirements from their trade union. Only 13 per cent of employees were aware that the requirements gave them a right to ask their employer about the future of their organisation (CHA, 2005: 4-5)

It might be that the choice of paths diversifies into high road and low road with the former providing for information and consultation, and the latter mostly being information-passing and psuedo-participation (Dundon, et al., 2005).

It could be argued that the history and context of the I\&C Directive passage into UK law and the implementation of the ICE Regulations potentially provide a guide to the future prospects of employee representation in the UK. While the ICE Regulations may provide greater information and consultation at the workplace, whether the laws provide greater influence in workplace decision-making is still open to debate.

\section{Conclusion}

Overall, these new legislative requirements on information and consultation would suggest that the old dichotomy of a union versus non-union channels of voice is likely to prove to be inadequate in shaping future representation arrangements. Instead the focus could be more effectively directed towards the quality of employee 
representation and resultant climate of employment relations, manifested in a mosaic of substance and process ${ }^{4}$. Embracing this alternative orientation has important consequences for management strategies and union responses to future information and consultation arrangements in establishing effective workplace representation.

\section{References}

Beaumont, P. \& Hunter, L. (2003) Information and Consultation: From Compliance to Performance. London: CIPD.

Bercusson, B. (2002) 'The European social model comes to Britain', Industrial Law Journal, 31 (3): 209-244.

Burns, P. (2000) The Silent Stakeholders: Reforming workforce consultation law. Policy paper, London: The Industrial Society.

CHA (2005) A Little More Conversation: Employee Communications Approaches and their Impact.

Chartered Management Institute (2002) Response to DTI Paper on High Performance Workplaces.

CIPD (2004) Information and Consultation: A Guide. United Kingdom: Chartered

\section{Institute of Personnel and Development.}

-(2005) The Information and Consultation Directive.

_-(2003) High Performance Workplaces_Informing and Consulting Employees.

London: Consultation Document, Department for Trade and Industry.

-(2004) DTI Guidance: The Information and Consultation of Employees

Regulations. Department of Trade and Industry.

Department of Trade and Industry (DTI) (2002) Green Paper High Performance

Workplaces: The Role of Employee Involvement in a Modern Economy: A

Discussion Paper. London: Department of Trade and Industry.

Dundon, T., Curran, D., Ryan, P. and Maloney, M. (2005), 'Conceptualising the dynamics of employee information and consultation: evidence from the Republic of Ireland', Industrial Relations Journal, 37(5): 492-512.

Emmott, M. (2003) Submission to DTI on Information and Consultation Directive.

Chartered Institute of Personnel and Development (CIPD).

\footnotetext{
${ }^{4}$ We would like to thank Professor David Marsden for this point.
} 
European Commission. (1998) Commission Adopts a Proposal for a Directive on

Information and Consultation of Employees. 11 November, Brussels (IP/98/981)

European Parliament and Council (2001) Statute for a European Company (SE).

Council Regulation No.2157/2001, 2001 OJ (L 294).

-(2001) Supplementing the Statute for a European Company with Regard to the Involvement of Employees. Council Directive 2001/86/EC, 2001 OJ (L 294).

_-(2002) A General Framework for Informing and Consulting Employees. Council Directive 2002/14/EC, 2002 OJ (L 080).

Fenton-O'Creevey, M., Wood, S. \& Callerot, E. (1998) Employee Involvement Within

European Multinationals. European Works Council Study Group, Stage 1

Research Report. July.

Fernie, S. and Metcalf, D. (1995) 'Participation, contingent pay, representation and workplace performance: evidence from Great Britain', British Journal of Industrial Relations, 33 (3): 379-415.

Gollan, P.J, (2005) 'Representative voice-the interplay between non-union and union representation arrangements at Eurotunnel', Advances in Industrial and Labor Relations, 14.

-(2006) Employee Representation in Non-Union Firms, Sage Publications, London, 2006

Gospel, H. \& Willman, P. (2002) The Right to Know: Disclosure of Information for Collective Bargaining and Joint Consultation in Germany, France, and Great Britain. London: Discussion Paper No.453, Centre for Economic Performance, London School of Economics.

_-(2003) 'The coming of workplace information sharing and consultation: what it means for employee representation in Britain', Perspectives on Work, 7 (1): 3839.

Hall, M. (2005) How are Employers and Unions Responding to the Information and Consultation of Employee Regulations. Warwick Papers in Industrial Relations. Hall, M., Broughton, A., Carley, M. \& Sisson, K. (2002) Works Councils for the UK? Assessing the Impact of the EU Employee Consultation Directive. London: IRS/IRRU.

Kelly, J. (1996) 'Works councils: union advance or marginalisation?’. In A. McColgan (ed.), The Future of Labour Law, pp. 47-63. London: Mansell. 
Kostova, T. \& Roth, K. (2002) 'Adoption of an organizational practice by subsidiaries of multinational corporations: institutional and relational effects', Academy of Management Journal, 45 (1): 215-233.

Linklaters, (2005) Informing and Consulting: Information and Consultation of Employees Regulations 2004. London: Linklaters.

Lloyd, C. (1999) 'What do Employee Councils do? Representation in non-union firms. Conference Proceeding, BUIRA Conference, De Montfort University, 1-3 July.

Marchington, M. \& Wilkinson, A. (2005) ‘Direct participation’. In S. Bach (ed.), Managing Human Resources: A Comprehensive Guide to Theory and Practice, $4^{\text {th }}$ Edition. Oxford: Blackwell.

Peccei, R., Bewley, H., Gospel, H. \& Willman, P. (2005) 'Is it good to talk? Information disclosure and organizational performance in the UK', British Journal of Industrial Relations, 43 (1 ): 11-39.

Reade, Q. (2005) 'Employees in the dark over forthcoming consultation rights', Personnel Today, $5^{\text {th }}$ April.

Sako, M. (1998) 'The nature and impact of employee "voice” in the European car components industry', Human Resource Management Journal, 9 (1): 5-13.

Scott, R. (2002) 'The UK and the Information and Consultation Directive Transposition or Transformation?', BUIRA (London) Information and Consultation Seminar, May 31, London.

Scott R(1995) Institutions and Organisations,. New York: Sage.

Sisson, K. (2002) The Information and Consultation Directive: unnecessary "regulation" or an opportunity to promote "partnership”? Warwick Papers in Industrial Relations, No.67. Coventry: Industrial Relations Research Unit (IRRU), Warwick University.

Thompson, P. (2003) Disconnected Capitalism, Work, Employment and Society, 17 (2): 359-378.

Wilkinson, A., Dundon, T., Marchington, M. \& Ackers, P. (2004) 'Changing patterns of employee voice, Journal of Industrial Relations, 46 (3): 298-322. 
Table I Prospects for Information and Consultation

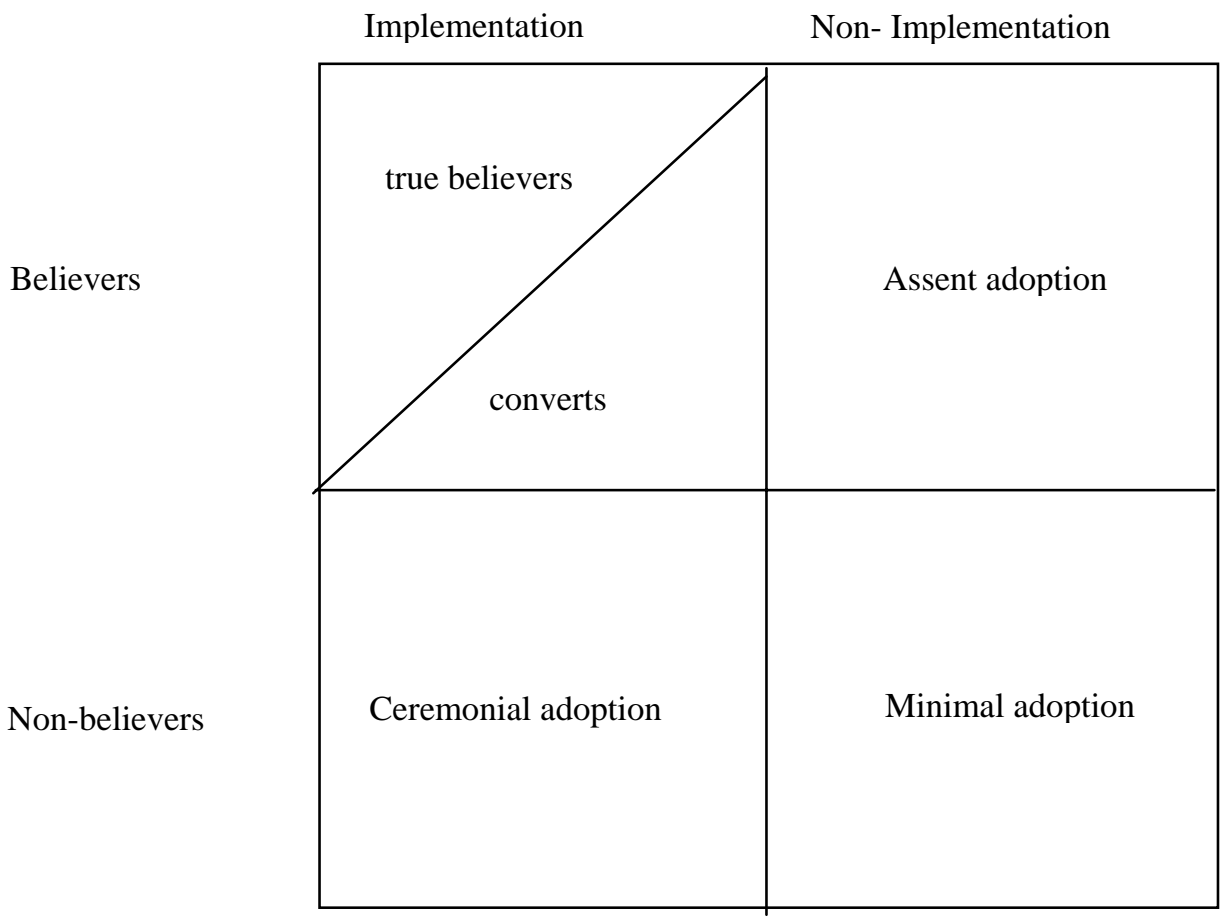

(Adapted from Kostova and Roth, 2002) 


\section{Box 1: Information and Consultation of Employees (ICE) Regulations 2004}

- The regulations apply to undertakings in Great Britain with 50 or more employees. Equivalent legislation will be made in respect of Northern Ireland.

The regulations come into force on 6 April 2005. The Regulations only apply to an 'undertaking' (for example, a company, partnership or sole trade) with a registered office, head office or principal place of business situated in Great Britian and employing 150 or more employees in the UK (from April 2007 this figure reduced to 100 and from April 2008 it becomes 50).

- The legal requirement to inform and consult employees is not automatic. A formal request has to be made by employees, or by an employer initiating the process (an employer notification).

An employer must establish information and consultation procedures where a valid request has been made by employees.

- Such a request must be made in writing by $10 \%$ of employees in an undertaking (subject to a minimum of 15 and a maximum of 2,500 employees). The Regulations permit a single or a specified group of requests sent to the employer or the Central Arbitration Committee (CAC).

- Where the employees making the request wish to remain anonymous, they can submit the request to an independent body (such as the Central Arbitration Committee of ACAS).

- An employer can continue with pre-existing information and consultation arrangements, provided that such arrangements have been agreed prior to an employee written request and:

i) the agreement is in writing, including any collective agreements with trade unions;

ii) the agreement covers all employees in the undertaking;

iii) the agreement sets-out how the employer is to provide the information and seek employee

views for consultation; and

iv) the arrangements have been agreed by the employees

- All employees must be entitled to take part in the appointment or election of the representatives. The election or appointment must be arranged in such a way that all employees will be represented.

- If an employee request is to change a pre-existing agreement already in place in an undertaking, then $40 \%$ plus a majority of those voting must endorse the request. The employer is then obliged to reach a negotiated agreement with genuine employee representatives. 
- Where fewer than $40 \%$ of employees endorse the request, the employer would be able to continue with pre-existing arrangements.

- The parties have 6 months to reach a negotiated agreement (extendable by agreement).

- Where a valid request (or employer notification) has been made, but no agreement reached, standard information and consultation provisions based on ICE Regulation 18 would apply.

- Where the standard information and consultation provisions apply, the employer shall arrange for a ballot to elect the employee representatives. Regulation 19 states that there shall be 1 representative per 50 employees, or part thereof, with a minimum of 2 and maximum of 25 representatives.

Information must be given in such time, and in such fashion and with such content as are appropriate to enable the information and consultation representatives to conduct an adequate study and, where necessary, prepare for consultation.

ICE Regulation 20 states that I\&C representatives, once elected, must have the opportunity to meet with the employer and give their opinion on matters subject to consultation, with a view to reaching agreement. The employer must give a reasoned response to I\&C representatives’ views.

A complaint regarding a negotiated agreement, or a failure to comply with standard provisions, must be brought to the CAC within 3 months of the alleged failure.

The ICE Regulations do not govern the enforcement of a 'pre-existing agreement'. This will depend upon the nature of the agreement. For example, if it is a legally binding agreement and the employer is in breach, proceedings can be brought in the High Court.

- Where the CAC uphold a complaint for failure to comply, the complainant may make an application to the Employment Appeal Tribunal (EAT). An appeal must be made within 42 days of the date on which written notification of the CAC declaration is sent.

The maximum penalty for failing to comply with a declaration made by the CAC is $£ 75,000$.

- ICE Regulations 25 and 26 provide for the confidentiality of sensitive information given to I\&C representatives.

I\&C representatives, and employees making a request, are protected against discrimination/unfair dismissal for exercising their rights under the ICE Regulations. I\&C representatives are to be afforded paid time-off to carry out their duties. Source: DTI, 2004 and Linklaters, 2005) 